
\title{
CIÊNCIA'NATURA
}

\section{Model rainfall-runoff in the constraints Amazon}

\author{
Modelo chuva-vazão nas restrições da Amazônia \\ Bruno Henrique Casavecchia ${ }^{1^{*}}$, frederico terra de almeida ${ }^{2}$, Adilson Pacheco de Souza $^{3}$, Cornélio \\ Alberto Zolin ${ }^{4}$, Eduardo Morgan Uliana ${ }^{5}$ and Adriana Marques ${ }^{6}$

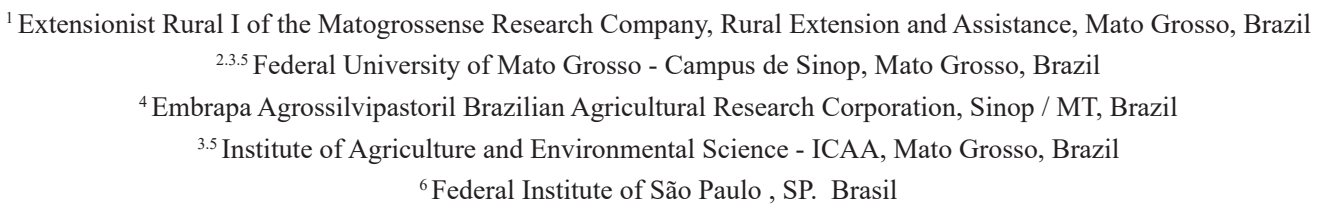

Abstract

The development of a hydrological model in Amazon region has been a challenge for researchers since historical series of hydrological data in the Amazon region are still insufficient. The aim of this study was based on different samples of settings for calibration and validation of IPH II model, using limited historical series of data of daily average water flow registered in Caiabi river hydrologic basin, a tributary stream of Teles Pires river- Mato Grosso. The total area of the study location is $440.98 \mathrm{~km} 2$, and there were installed three meteorological automatic stations for climate monitoring, and one linigraph in the basin end for monitoring the altimetric quotas and also to estimate the daily water flow of the river. The precipitation data, evapotranspiration and water flow used to feed the IPH II model were collected between 09/18/2015 and 04/30/2016, using sixty percent of the initial historical data to calibrate and forty percent to validate the model has shown better statistic performance, however rearranging the data and establishing the sixty percent of the central data for the calibration was verified that there was an increase in the statistical performance of the model making the simulations of the IPH II model were successful. It was indicated by the results that the sample methodology for calibration of hydrologic models can bring substantial improvement to the performance.

Keywords: Hydrologic simulation; IPH II model; Small serial data

\section{Resumo}

Séries históricas de dados hidrológicos na região amazônica ainda são escassos, tornando a modelagem hidrológica um desafio nessa região. O objetivo desse estudo foi testar diferentes arranjos para calibração e validação do modelo IPH II, utilizando-se de uma pequena série de dados de vazões médias diárias registrada na bacia hidrográfica do rio Caiabi, afluente do rio Teles Pires - Mato Grosso. A área de estudo possui 440,98 km2, onde foram instaladas 3 estações meteorológicas automáticas para monitoramento climático, e um linígrafo no exutório da bacia para monitoramento das cotas e estimar as vazões diárias do rio. Os dados de precipitação, evapotranspiração e vazão usados para alimentar o modelo IPH II foram coletados entre 18/09/2015 a 30/04/2016. Usando $60 \%$ dos dados iniciais da série para calibrar e 40\% finais para validar, o modelo apresentou o melhor desempenho estatístico, entretanto quando se rearranjou os dados, estabelecendo que $60 \%$ do meio da série de dados seriam para calibração, conseguiu-se um aumento do desempenho estatístico do modelo, tornando as simulações do modelo IPH II satisfatórias. Os resultados indicam que a escolha do método da amostragem dos dados para a calibração de modelos hidrológicos, pode melhorar substancialmente o desempenho dos mesmos.

Palavras-chave: Simulação hidrológica; Modelo IPH II; Pequena série de dados

*brunohcasavecchiaef@gmail.com 


\section{Introduction}

Reliable historical series of data related to river flows are scarce in Brazil due to the large territorial extension, large quantities of rivers and the lack of investments in hydrological monitoring. In the Amazon watershed, the quantitative monitoring stations are smaller when compared to the Southern and Southeastern regions of the country (NETO et al., 2008), increasing the difficulties in the application of hydrological models in the Amazonic region.

In the absence of reliable data, the application of semi-distributed and distributed hydrological models can present unreliable results as these models require a large amount of spatial and temporal data. The water-flow hydrological models are more suitable for this reality since they require small amount of input data and present great potential to extend series of flows in the watershed where there is monitoring of precipitations (TUCCI, 2009). The rainfall-runoff models are important hydrological studies to improve processes that occur with rain and runoff, can be useful in solving problems such as drainage infrastructure, flood forecasting, urban planning and use of the soil (CHANG et al., 2018)

Pereira et al. (2016b) compared the performance of the two hydrological models - semi distributed (SWAT) and rainfall-runoff (IPH II) in the simulation of flow in hydrograph basin of Pombo river in the state of Minas Gerais, finding better performance in the rainfall-runoff model after using four years in the calibration of the standards of the model and two years for its validation. Chlumecký et al. (2017) evaluating some methods of calibration of rainfall model can conclude that this type of model can efficiently describe the environmental processes involved in surface runoff. Machado et al. (2017) applied rainfall model in two hydrographic basins of the state of São Paulo and concludes that the results are satisfactory despite the simplicity of the model.

The monitoring and the use of the hydrologic models are important to the applicability of damming, protective dikes, drainage channels, fore sighting of drought and floods and support to the granting procedure what have been showing great demand. In Brazil the usage of rainfall-runoff models is still restricted to the monitoring of the power plant reservoir making use of precipitation and another climate information (MELLER et al., 2014). The hydrologic models are significant while estimating the river flow on short and medium terms and the hydrological response in hydrographic basins considering the changes in usage and land occupation.

In order to apply the hydrological models for these endings it is mandatory quality and reliability while predicting the hydrological behavior so it can be used as a tool in the management of hydric resources (PEREIRA et al., 2016a).

Considering those aspects, the calibration of the model parameters is necessary so the simulated values are coherent to the observed data by using either the manual or the automatic way. (TUCCI, 2009) Taking that into account, the aim of this paper is to assess the calibration and validation of the rainfall-runoff IPH II model under different settings of data in order to enable the usage of limited series of data of Amazonic watershed to simulate the daily water flows.

\section{Materials and Methods}

\subsection{Study Area}

The place of study corresponds to the watershed of the river Caiabi (BHRC), inserted in the hydrographic region of the Amazon, being part of the watershed of the Teles Pires river with the area of $440.98 \mathrm{~km}^{2}$ and perimeter of $182.65 \mathrm{~km}$ (DORNELES, 2015), located in the middle of the North region of the State of Mato Grosso according to Figure 1.

According to the Thornthwaite classification, the climate of the region is of the type B2wA"a" (Humid presenting moderate hydric deficiency in the winter, with evapotranspiration potential greater than or equal to $1140 \mathrm{~mm}$ with less than $48 \%$ of the evapotranspiration concentrated in the summer). The rainfall average is $1974 \mathrm{~mm}$ concentrated in the summer/autumn and hydric deficiencies in the winter/spring. (SOUZA et al., 2013).

The climatic and fluviometric information of BHRC was monitored by the stations listed on table 1.

Table 1 - Hydroclimatic station of BHRC

\begin{tabular}{c|c|c|c|c}
\hline Name & Station & Lat & Long & Alt \\
\hline Caiabi River & Fluviometric & $-12,158$ & $-55,478$ & 327 \\
\hline São José & Meteorologic & $-12,172$ & $-55,404$ & 376 \\
\hline Fetter & Meteorologic & $-12,264$ & $-55,307$ & 382 \\
\hline Bedin & Meteorologic & $-12,407$ & $-55,362$ & 390 \\
\hline G. Celeste & Meteorologic & $-12,288$ & 56,294 & 385 \\
\hline
\end{tabular}

Lat = latitude; Long = longitude; Alt = altitude; G. Celeste = Gleba Celeste; 
Figure 1 - Location map and instrumentation of the basin area of river Caiabi

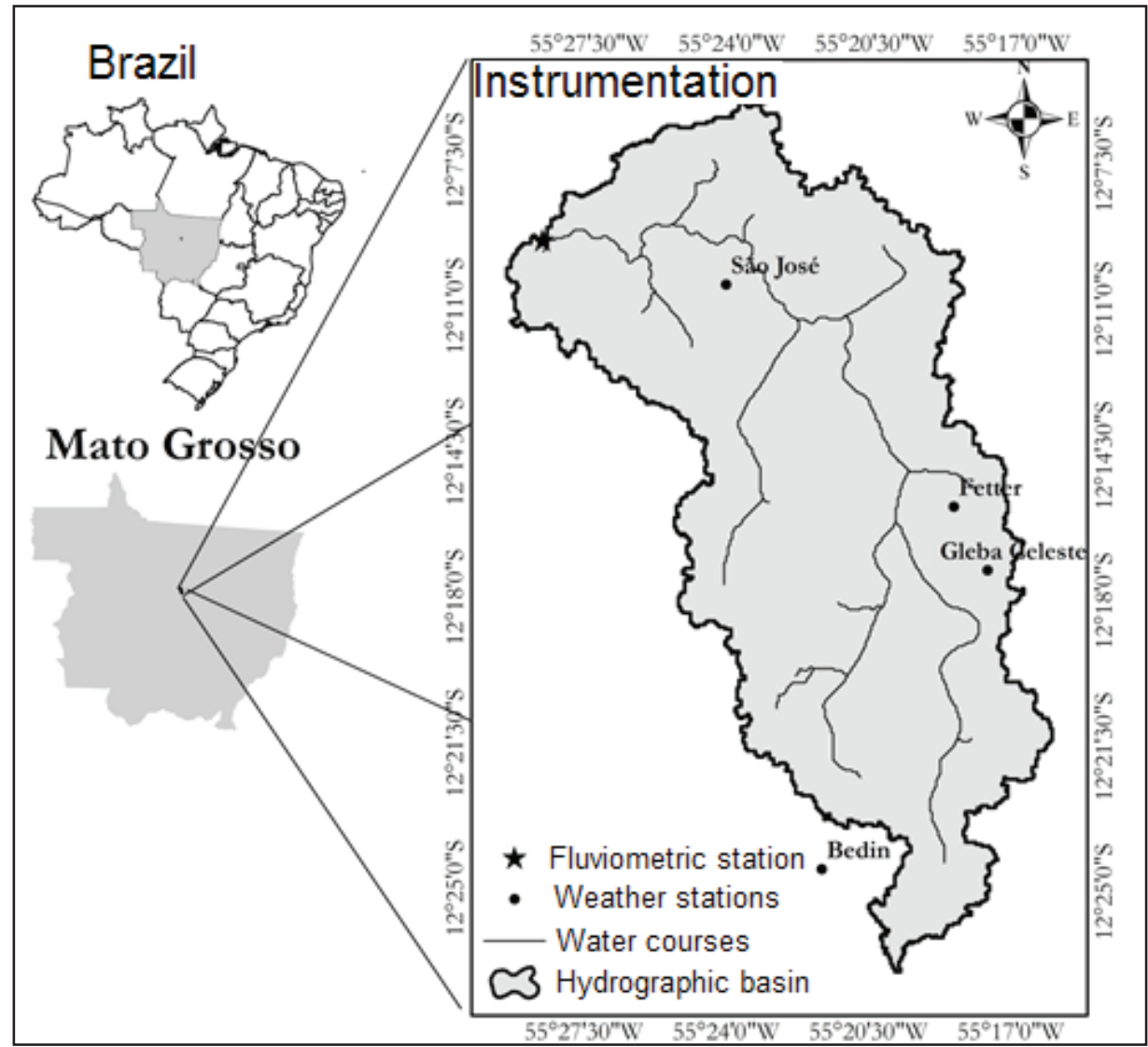

\subsection{IPH II Model}

The IPH II (TUCCI, 2005) is a concentrated and deterministic model that requires as input variables precipitation data and reference evapotranspiration. The precipitation of the BHRC was calculated by the method of the arithmetic average with the data of the meteorological stations São José, Fetter and Bedin. The method of estimation of the reference evapotranspiration $\left(\mathrm{ET}_{0}\right)$ used in this study was that of Camargo (1999), recommended to region according to the work of Tanaka et al. (2016).

The IPH II model uses specific algorithms related to evaporation and interception loss, separation of runoff, propagation of the superficial runoff and propagation of the underground runoff, according to detailed description in Bravo et al. (2006). Follows below a brief description of the IPH II model.

When the evapotranspiration is lower than precipitation in the model, it is deducted from precipitation and, when the evapotranspiration is greater than the precipitation met by the interception reservoir (permeable areas and depressions), at the time depletion of the reservoir occurs, the evapotranspiration is treated by water in the soil by means of the linear relation presented in equation 1 .

$$
E_{t}=\frac{E_{0} \cdot S_{t}}{S_{\text {máx }}}
$$

Being, $\mathrm{E}_{\mathrm{t}}$ bulk evapotranspiration in time $\mathrm{t} ; \mathrm{ET}_{0}$ is reference evapotranspiration; $\mathrm{S}_{\mathrm{t}}$ is the content of water in soil per time; $\mathrm{S}_{\max }$ is the maximum amount/content of water in the soil.

The modified Horton algorithm is used to separate the superficial runoff, resulting in two equations (Equation 2 and 3 ) that relate storage with infiltration and percolation.

$$
S_{t}=a_{i}+b_{i} . l_{t}
$$

$$
S_{t}=a_{t}+b_{t} \cdot T_{t}
$$


where,

$$
\begin{aligned}
& a_{i}=\frac{\left(-I_{0}^{2}\right)}{\left[\ln (h) \cdot\left(1_{0}-I_{b}\right)\right]} \\
& b_{i}=\frac{I_{0}}{\left[\ln (h) \cdot\left(I_{0}-I_{b}\right)\right]} \\
& b_{t}=\frac{\left(-I_{0}\right)}{\left[\ln (h) \cdot I_{b}\right]}
\end{aligned}
$$

where, $\mathrm{S}_{\mathrm{t}}$ is the water content in the soil at time $\mathrm{t}(\mathrm{mm})$; $\mathrm{h}$ is $\mathrm{e}^{-\mathrm{K}}$, being $\mathrm{K}\left(\mathrm{h}^{-1}\right)$ a parameter that characterizes the exponential decay of the infiltration curve and depends on the characteristics of the soil; $\mathrm{I}_{0}$ is the ability to infiltrate the soil when the water content is $\mathrm{S}_{0}\left(\mathrm{~mm} \mathrm{~d}^{-1}\right)$; And $\mathrm{I}_{\mathrm{b}}$ is the infiltration capacity when the soil is saturated $\left(\mathrm{mm} \mathrm{d}^{-1}\right)$.

The surface volume propagation is made to the main section of the basin with the Clark method, which consists of a combination of the time-area histogram (HTA) with a simple linear reservoir (TUCCI, 2005).

Superficial runoff is defined by the simple linear reservoir method, through Equation 7

$$
Q_{S(t+1)}=Q_{S(t)} \cdot e^{-\frac{\Delta t}{\Delta K_{S}}}+V_{S(t+1)} \cdot\left(1-e^{-\frac{\Delta t}{\Delta K_{S}}}\right)
$$

where, $Q_{S}(t)$ is the superficial flow in the instant $t\left(\mathrm{~mm} \mathrm{~d}^{-1}\right) ; K_{S}$ is the average emptying time of the superficial reservoir (d); $V_{s}$ is the effective precipitation in time t obtained whereby the HTA $(\mathrm{mm})$.

The spread of underground runoff is also obtained by the simple linear reservoir method by means equation 8 :

$$
Q_{\text {Sub }(t+1)}=Q_{\text {Sub }(t)} \cdot e^{-\frac{\Delta t}{\Delta K_{\text {Sub }}}}+V_{p(t+1)} \cdot\left(1-e^{-\frac{\Delta t}{\Delta K_{\text {Sub }}}}\right)
$$

where, $\mathrm{Q}_{\text {Sub }}(\mathrm{t})$ is the underground flow at instant $\mathrm{t}\left(\mathrm{mm} \mathrm{D}^{-1}\right) ; \mathrm{K}_{\text {Sub }}$ is the average emptying time of the underground reservoir $(\mathrm{d}) ; \mathrm{V}_{\mathrm{p}}$ is the percolated volume $(\mathrm{mm})$.

The $\mathrm{I}_{0}$ parameters (initial infiltration capacity), $\mathrm{I}_{\mathrm{b}}$ (minimum infiltration capacity), $\mathrm{h}$ (parameter that characterizes the exponential decay of the infiltration curve and depends on the characteristics of the soil), $\mathrm{K}_{\text {Sub }}$ (average aquifer emptying time), $\mathrm{K}_{\text {Sup }}$ (surface drain delay time), $\mathrm{T}_{\mathrm{c}}$ (concentration time), $\mathrm{R}_{\text {máx }}$ (initial loss reservoir volume) and Alpha (model parameter used in calculating the percentage of precipitation that drains superficially) were obtained by calibration.

\subsection{Data}

In this study the data entered in the model were precipitation, evapotranspiration and flow, which were monitored by 3 Davis meteorological stations and the flows, were estimated by key curve through the dimensions recorded by a Thalimeds linigraph model, OTT brand.

The data series used starts on 09/18/2015 and was ended on 04/30/2016. The data was set for calibration and validation of the IPH II model with the respective percentages: $50-50 \%, 60-40 \%, 70-30 \%$ and $80-20 \%$, in a way the best settlement was found and then some tests were carried out in an attempt to improve the performance of the model.

\subsection{Statistics}

The evaluation performance of the IPH II model in calibration and validation was conducted whereby the following precision statistics: Nash-Sutcliffe coefficient $(E)$, Nash-Sutcliffe $\log \left(E_{\log }\right)$, coefficient of determination, $\left(R^{2}\right)$, average absolute error (MAE), quadratic error root (RMSE) and Willmott (d) Concordance (WILMOTT, 1982; Legates, MACCBE, 1999; KRAUSE et al., 2005).

\section{Results and Discussion}

The quantitative measures of the performance of the model IPH II are displayed on table 2, in different settings of the data series used in the calibration and validation stages. 
The analysis of the volume ratio observed with the calculated volume $\left(\mathrm{V}_{\mathrm{o}} / \mathrm{V}_{\mathrm{c}}\right)$ indicates that in the calibration phase of the model IPH II the simulations of the flows in the settings $60-40 \%, 70-30 \%$ and $80-20 \%$ were underestimated, and overestimated in the settings $50-50 \%$. Nevertheless, in the validation phase, the relationship $\mathrm{V}_{\mathrm{o}} / \mathrm{V}_{\mathrm{c}}$ indicated the sub estimation of the simulated flows by the IPH II model in the settings 50-50\% and 70-30\%, and overestimation in the settings $60-40 \%$ and $80-20 \%$.

The $60-40 \%$ settings presented the highest determination coefficients (R2) in the calibration being $0.065 \%$ higher than the second place; In the validation the $80-20 \%$ setting was the one that showed the highest coefficient of determination. These values are similar to those found by Germano et al. (1998) while applying the IPH II model in the simulation of flows in small urban watersheds. According to Legates and MACCBE (1999), being the coefficient of determination an indicative of precision, the conclusions based only on that coefficient may be mistaken, making necessary the application and interpretation of a set of statistical indexes to avoid mistakes (PEREIRA et al., 2016b).

Table 2 . Quantitative measures of the performance of the IPH II hydrological model, in the settings of 50-50\%, 60-40\%, 70-30\% and $80-20 \%$

\begin{tabular}{|c|c|c|c|c|c|c|c|c|}
\hline Settings & Stage & $\mathrm{V}_{\mathrm{o}} / \mathrm{V}_{\mathrm{c}}$ & $\mathrm{R}^{2}$ & E & $E_{\log }$ & $\begin{array}{l}\text { MAE } \\
\mathrm{m}^{3} \mathrm{~s}^{-1} \\
\end{array}$ & $\begin{array}{l}\text { RMSE } \\
\left(\mathrm{m}^{3} \mathrm{~s}^{-1}\right)^{2}\end{array}$ & d \\
\hline \multirow{2}{*}{$50-50 \%$} & Calibration & 0,996 & 0,439 & 0,415 & 0,410 & 0,272 & 0,339 & 0,804 \\
\hline & Validation & 1,144 & 0,050 & $-0,366$ & $-0,342$ & 1,424 & 2,056 & 0,410 \\
\hline \multirow{2}{*}{$60-40 \%$} & Calibration & 1,013 & 0,780 & 0,764 & 0,717 & 0,312 & 0,374 & 0,936 \\
\hline & Validation & 0,969 & 0,638 & 0,531 & 0,548 & 1,054 & 1,252 & 0,784 \\
\hline \multirow{2}{*}{$70-30 \%$} & Calibration & 1,014 & 0,646 & 0,619 & 0,598 & 0,417 & 0,517 & 0,889 \\
\hline & Validation & 1,168 & 0,549 & 0,001 & $-0,102$ & 1,359 & 1,935 & 0,615 \\
\hline \multirow{2}{*}{$80-20 \%$} & Calibration & 1,012 & 0,715 & 0,704 & 0,693 & 0,478 & 0,643 & 0,915 \\
\hline & Validation & 0,882 & 0,783 & $-0,092$ & $-0,196$ & 1,520 & 1,744 & 0,629 \\
\hline
\end{tabular}

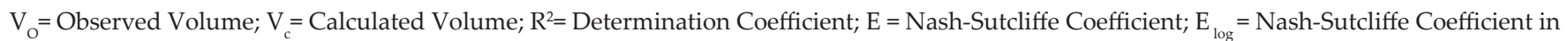
the logarithm scale; $M A E=$ absolute average error; RMSE = Average square error; $d$ = Coefficient of Wilmot

The evaluation of the accuracy of the simulations of the flows generated by the different settings, through the coefficient of Nash-Sutcliffe (E), indicated superiority of the settings $60-40 \%$ in relation to the others. According to Silva et al. (2008), the values of the Nash-Sutcliffe coefficient (E) above 0.75 indicates reliable performance of the model, and between 0.36 and 0.75 acceptable performance what demonstrates that, the IPH II model even being calibrated and validated with a limited series of data, showed satisfactory performance found, when the arrangement was used with $60 \%$ of the data for calibration and $40 \%$ for validation.

Several hydrological modeling works are found in the literature, with a wide variation of the values of Nash-Sutcliffe (E), all attribute these variations to inconsistency of the input data of the model, errors of obtaining data in the measures stations, the non-distribution of soil parameters in the watershed and also in distributed models (BLANCO et al., 2007; PAIVA et al., 2011; ASADZADEH et al., 2016; PEREIRA et al., 2016a).

Applying the Nash-Sutcliffe log, the values found in the validation improved $(0.548)$ in the $60-40 \%$ arrangement, this is the case in which the Nash-Sutcliffe log makes the weight of the errors of the smallest and highest equivalent flows, demonstrating the accuracy of the model while simulating the downturn flows of hydrogram (KRAUSE et al., 2005).

The deviations presented (MAE) by the different settings used to calibrate and validate the model IPH II, showed that the $50-50 \%$ arrangement obtained the best adjustment, with its predictions deviation around 5\% in relation to the observed data. However, the $60-40 \%$ arrangement was the one which presented less deviation in the validation phase, with $12.6 \%$ when compared to the average of the observed data. The deviations found were minor in the study of Pereira et al. (2016b) in which the deviation represented $18 \%$ of the average observed in the calibration and $20.6 \%$ in the validation.

The spreading (RMSE), demonstrated that the variation of the simulated values for the same observed value (Oak et al.,2015) in the calibration with the arrangement $50-50 \%$, presented the smallest error and in the validation of the $60-40 \%$ arrangement.

The index of Wilmott (d) (table 2) showed that calibration and validation using the 60-40\% arrangement obtained good adjustments (0.936 and 0.784), because the closer to 1 the better the accuracy of the model (Wilmott, 1982).

According to the statistics Standards, the $60-40 \%$ setting presented better performance than the others. While trying to enhance results, the process was inverted using $60 \%$ of the final data of the series for calibration and $40 \%$ of the initial data for validation. By analyzing Table 3 we can see that the Determination Coefficient $\left(\mathrm{R}^{2}\right)$, Nash-Sutcliffe (E), Nash-Sutcliffe logarithm $\left(\mathrm{E}_{\mathrm{log}}\right)$ and Willmott Index $(\mathrm{d})$, presented lower values when compared to the findings of the calibration- validation $60-40 \%$. The MAE (absolute average error) and the RMSE (average square error) presented higher values in calibration and lower values in validation phases. 
Table 3 - Quantitative measures of the performance of the IPH II hydrological model, in the settings of $60 \%_{\text {Cal }}-40 \%{ }_{\text {Val }}, 40 \%{ }_{\text {Val }}$ $60 \%_{\text {Cal }}, 20 \%_{\text {Val }}-60 \%_{\text {Cal }}-20 \% \%_{\text {Val }}$

\begin{tabular}{c|c|c|c|c|c|c|c|c}
\hline \multirow{2}{*}{ Settings } & Phase & $\mathrm{V}_{\mathrm{o}} / \mathrm{V}_{\mathrm{c}}$ & $\mathrm{R}^{2}$ & $\mathrm{E}$ & $\mathrm{E}$ & $\mathrm{MAE}$ & $\mathrm{RMSE}$ & $\mathrm{d}$ \\
\hline \multirow{2}{*}{$60 \%_{\mathrm{Cal}}-40 \%_{\text {Val }}$} & Calibration & 1,013 & 0,780 & 0,764 & 0,717 & 0,312 & 0,374 & 0,936 \\
\cline { 2 - 10 } & Validation & 0,969 & 0,638 & 0,531 & 0,548 & 1,054 & 1,252 & 0,784 \\
\hline \multirow{2}{*}{$40 \%_{\text {Val }}-60 \%_{\text {Cal }}$} & Calibration & 0,977 & 0,610 & 0,569 & 0,583 & 0,858 & 1,138 & 0,828 \\
\cline { 2 - 9 } & Validation & 1,117 & 0,263 & $-3,335$ & $-4,123$ & 0,621 & 0,707 & 0,486 \\
\hline \multirow{2}{*}{$20 \%_{\text {Val }}-60 \%_{\text {Cal }}-20 \%_{\text {Val }}$} & Calibration & 1,004 & 0,670 & 0,660 & 0,661 & 0,398 & 0,497 & 0,900 \\
\cline { 2 - 9 } & Validation & 1,099 & 0,835 & 0,727 & 0,783 & 0,830 & 1,187 & 0,914 \\
\hline
\end{tabular}

$\mathrm{V}_{\mathrm{O}}=$ Observed Volume; $\mathrm{V}_{\mathrm{c}}=$ Calculated Volume; $\mathrm{R}^{2}=$ Determination Coefficient; $\mathrm{E}=$ Nash-Sutcliffe Coefficient; $\mathrm{E}_{\log }=$ Nash-Sutcliffe Coefficient in the logarithm scale; $M A E=$ absolute average error; $\mathrm{RMSE}=$ Average square error; $\mathrm{D}=$ Coefficient of Wilmot.

While using the $60 \%$ range of data in the middle of the data series and validating with $20 \%$ of the initial and final data, the IPH II model underestimated the values of the observed flow rates in both the calibration and the validation, being the coefficients of $\left(\mathrm{R}^{2}\right)$, Nash-Sutcliffe $(\mathrm{E})$ and Nash-Sutcliffe $\log \left(\mathrm{E}_{\mathrm{log}}\right)$ increased by around 30.9, 36.9 and 42.9\%, when compared to the $60 \%$ Cal- $40 \%$ Val setting in the validation.

The absolute average error (MAE) and the Average Square Error (RMSE) in the calibration of the 20\% Val-60\% Cal-20\% Val setting were higher than in the $60 \%$ Cal-40\% Val setting, considering that in validation the errors decreased around 21.2 and $5.2 \%$ in relation to the setting $60 \%$ Cal- $40 \%$ Val.

Considering the hydrographs of the daily average flows observed and simulated by the IPH II model in Figure 2, it is observed that the use of the $20 \%$ Val- $60 \%$ Cal-20\% Val setting, the sampling of the data used in the calibration can better represent the larger flows and smaller, reflecting a better validation performance (TUCCI, 2009).

It is possible to observe agreement between the data observed and simulated by IPH II, but in all settings the model had difficulty in representing the peak values, mainly in the validation. According to Pereira et al. (2016b) peak values are naturally difficult to simulate by hydrological models due to rainfall variability and low concentration time in river basins. This difficulty is also found by Andrade (2013) and Pereira et al. (2014a, 2014b).

Table 4 shows the calibrated parameters of the IPH II model, of the $60-40 \%$ arrangement variations.

The parameter $\mathrm{I}_{0}$ ranged from 10.000 to $37.971 \mathrm{~mm} \mathrm{~h}-1$, indicating that on the $20 \%$ Val- $60 \%$ Cal-20\% Val calibration model it is identified less humidity in the soil, obtaining higher values of water infiltration in the soil at the beginning of precipitations (Jarvis et al., 2013) being those influenced by the low frequency of rainfall and not allowing the soil drenching (LIU; CHEN, 2015).

The values of $\mathrm{I}_{b}$, ranged from 5.122 to $9.999 \mathrm{~mm} \mathrm{~h}^{-1}$, and were higher than those found for Germano et al. (1998), 0.1 to 0.6 $\mathrm{mm} \mathrm{h}^{-1}$, in small urban watersheds; and Pereira et al. (2016b), who found $2.440 \mathrm{~mm} \mathrm{~h}^{-1}$ in a hydrographic basin area of $1650 \mathrm{~km}^{2}$.

According to Alagna et al. (2016), $\mathrm{I}_{\mathrm{b}}$ referred to infiltration speed when all the porosity of the soil is filled with water. Under such conditions, the pore continuity directly affects values of infiltration. The land use in the area of the hydrographic basin of Caiabi river, in its vast majority, is formed by rotative agriculture of soy and corn, what may contribute to stability of aggregates (MALIK et al., 2012) and total porosity- micro and macroporosity (WENDLING, 2012), increasing the continuity of pores, and so improving the hydraulic conductivity of these soils. These facts may justify the largest $I_{b}$ values found in relation to those found for Germano et al. (1998) and Pereira et al. (2016b).

Table 4-HPI model II parameters obtained in the calibration phase

\begin{tabular}{c|c|c|c|c|c|c|c}
\hline Percentage & $\begin{array}{c}\mathrm{I}_{\mathrm{o}} \\
\left(\mathrm{mmh}^{-1}\right)\end{array}$ & $\begin{array}{c}\mathrm{I}_{\mathrm{b}} \\
\left(\mathrm{mmh}^{-1}\right)\end{array}$ & $\mathrm{h}$ & $\begin{array}{c}\mathrm{K}_{\text {sup }} \\
(\mathrm{h})\end{array}$ & $\begin{array}{c}\mathrm{K}_{\text {sub }} \\
(\mathrm{h})\end{array}$ & $\begin{array}{c}\mathrm{R}_{\max } \\
(\mathrm{mm})\end{array}$ & $\begin{array}{c}\text { ALFA } \\
\text { (1, }\end{array}$ \\
\hline $60-40 \%$ & 11,488 & 9,999 & 0,080 & 30,438 & 142,277 & 0,0000200 & 19,999 \\
\hline $40 \%_{\text {Val }}-60 \%_{\text {Cal }}$ & 10,000 & 5,912 & 0,010 & 21,632 & 50,922 & 0,0000002 & 99,999 \\
\hline $20 \%_{\text {Val }}-60 \%_{\text {Cal }}-20 \%_{\text {Val }}$ & 37,971 & 5,122 & 0,010 & 29,532 & 80,030 & 0,0000040 & 9,998 \\
\hline
\end{tabular}

$(\mathrm{I} 0)=$ initial infiltration capacity $(\mathrm{Ib})=$ minimum infiltration capacity, $\mathrm{h}=$ soil type, $(\mathrm{Ksub})=$ average time of emptying of the aquifer, $($ Ksup $)=$ lag time of runoff, $($ Rmáx $)=$ volume of initials losses of reservoir, Alpha parameter used in the calculation of the percentage of precipitation that drain superficially (Bravo et al., 2006). 
Figure 2 - Hydrograph of the average daily flows observed and estimated by the IPH II hydrological models, in the different arrangements and the hietogram of the analyzed period, from $09 / 18 / 2015$ to $04 / 30 / 2016$

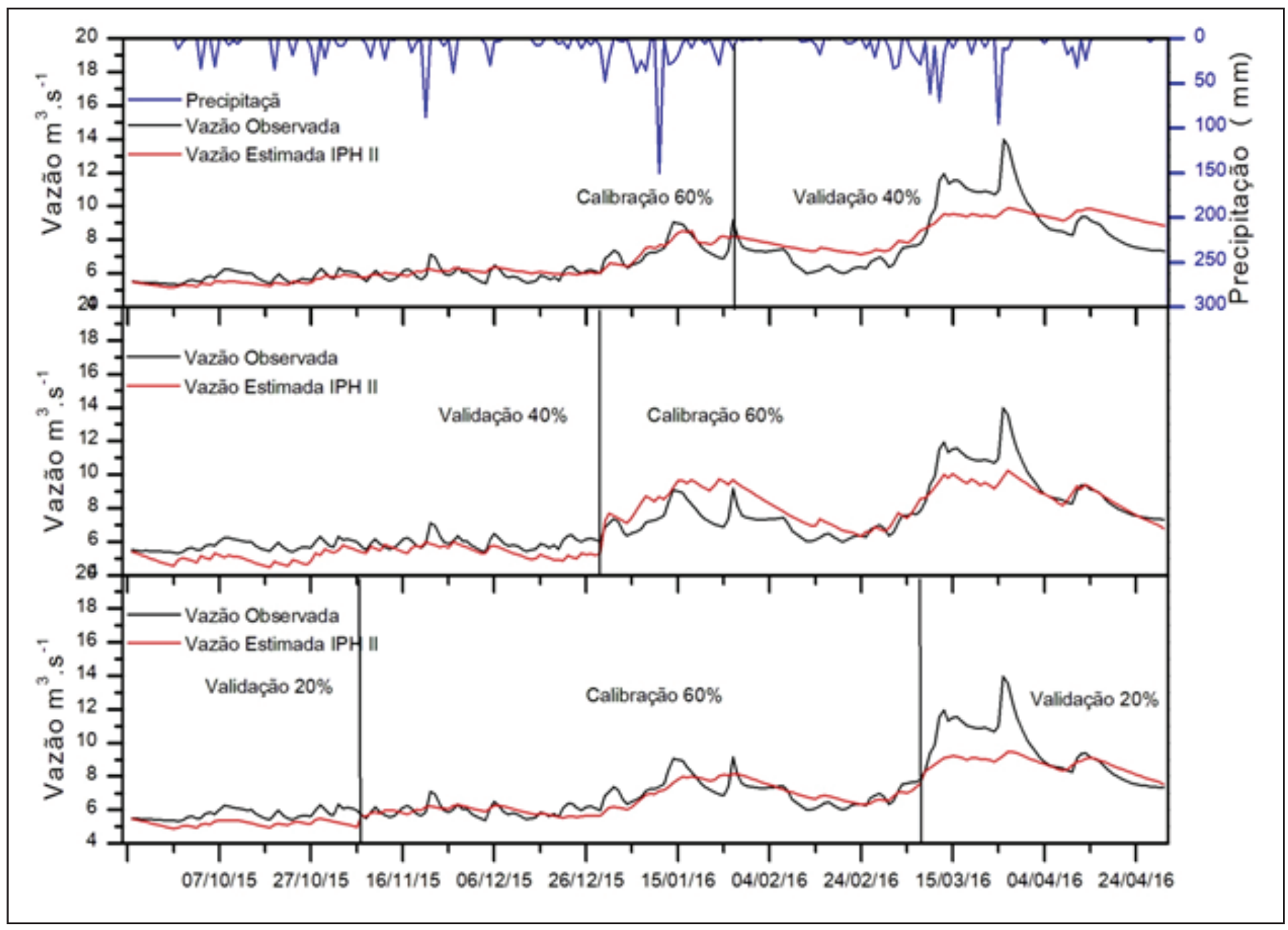

Nevertheless, the parameter h, presented lower values to those found in the study of Germano et al. (1998), from 0.5 to 0.94; and Pereira et al., (2016b) with the value of 0.706. According to Bravo et al. (2006) h is an empirical parameter related to the type of soil, and the highest values found by these authors may be related to high urbanization, proofing the watershed soils studied.

The runoff delay time $\left(\mathrm{K}_{\text {Sup }}\right)$ ranged from 21.632 to 30.438 , values higher than the ones found by Germano et al. (1998), from 0.5 to 20; and Pereira et al. (2016b), 2.209 and Moreira et al. (2007), 6 to 9, in calibration per event. For the parameter $\mathrm{K}_{\mathrm{Sub}}$ (average time of emptying of the aquifer) values ranged from 50.922 to 142.277 hours, higher than the values found by Germano et al. (1998), Pereira et al. (2016b) and Moreira et al. (2007), showing that small amplitudes of flow rates recorded are related to the behavior of water in the soil and the soil type.

The $\mathrm{R}_{\max }$ presented values from 0.0000002 to $0.0000200 \mathrm{~mm}$, showing that in the water catchment area of the river Caiabi hydrographic basin interception of precipitation is very low, probably due to relief plan, and the alpha ranged from 9.998 to 99.999, demonstrating little water available for runoff.

With the completion of this study it was found that there is a deficit of studies in the literature that attempt to correlate the performance of hydrological models with the variation of the amount of data used for calibration and validation. In most cases, the authors use between 60 to $70 \%$ of the series of data to calibrate and 40 and $30 \%$ to validate the models, but the results found in this work indicate that there are several settings that can improve the performance of hydrological models and enable the use of small historical series of data.

Despite the difficulties faced while instrumenting and monitoring the water area of the river Caiabi hydrographic basin, studies were to continue to turn viable the application of hydrological models in this area. 


\section{Conclusion}

The different settings used for the calibration and validation of the IPH II model demonstrated to be a potential technique in order to calibrate and validate the rainfall-runoff hydrological models, under restricted data conditions.

Regardless the short series of data used in this study, statistical indexes show that the simulations made with the IPH II model were satisfactory for the hydrographic basin of river Caiabi, indicating a functional tool for managing water resources in the Amazon region lacking spatially and temporally data.

Despite the simplicity of the rainfall models, they presented precise results even though there were data restrictions, placing them as an alternative of use in the regions that have little monitoration, such as the Brazilian Amazon.

\section{Acnowledgements}

We would like to thank the Fundação de Amparo a Pesquisa do Estado de Mato Grosso for the Masters' scholarship given to the first author, the partnership made with the Empresa Brasileira de Pesquisa Agropecuária (EMBRAPA-Agrossilvipastoril), who lent the linigraph used in this study and the rural producers for taking the area for hydro-meteorological equipment installation, and to the Conselho Nacional de Desenvolvimento Científico e Tecnológico (CNPq) by means of the financing of a great part of the research with the promotion granted in Edital CNPq No. 014/2011.

\section{References}

Alagna V, Bagarello V, Di Prima S, Giordano G, Lovino M. Testing infiltration run effects in the estimated water transmission properties of a sandy-loam soil. Geoderma. 2016;267:24-33.

Andrade MA, Mello CR, Beskow S. Simulação hidrológica em uma bacia hidrográfica representativa dos Latossolos na região Alto Rio Grande, MG. Revista Brasileira de Engenharia Agrícola e Ambiental, Campina Grande, 2013;17(1):69-76.

Asadzadeh M, Leon L, Yang W, Bosch D. One-day offset in daily hydrologic modeling: An exploration of the issue in automatic model calibration. Journal of Hydrology. 2016;534:164-177.

Blanco CJC, Yves S, Favre A. Análise, aplicação e transposição de um modelo chuva-vazão para simulação de curvas de permanência de pequenas bacias da Amazônia. Revista Brasileira de Recursos Hídricos. 2007;12(1):205-216.

Bravo JM, Allasia D, Collischonn W, Tassi R, Meller A, Tucci CEM. WIN-IPH2: manual de conceitos. Porto Alegre: Instituto de Pesquisas Hidráulicas; 2006.

Camargo AP, Marin FR, Sentelhas PC, Picini AG. Ajuste da equação de Thornthwaite para estimar a evapotranspiração potencial em climas áridos e superúmidos, com base na amplitude térmica diária. Revista Brasileira de Agrometeorologia. 1999;7(2):251-257.

CHANG TK, TALEI A, QUEK C, PAUWELS VRN. Rainfall-Runoff modelling using a self-reliant fuzzy inference network with flexible structure, Journal of Hydrology 2018, doi: https://doi.org/10.1016/j.jhydrol.2018.07.074

CHLUMECKÝ M, BUCHTELE J, RICHTA K. Application of random number generators in genetic algorithms improve rainfall-runoff modelling. Journal of Hydrology. 2017; 553:350-355

DORNELES JI. Caracterização física da microbacia hidrográfica do rio Caiabi com vista em reflorestamento compensatório [monography]. Sinop: Curso de Engenharia Florestal/UFMT, 2015.

Germano A, Tucci CEM, Silveira ALL. Estimativa dos parâmetros do modelo IPH II para algumas bacias urbanas brasileiras. Revista Brasileira de Recursos Hídricos. 1998;3(4):103-120.

Jarvis N, Koestel J, Messing I, Moeys J, Lindahl A. Influence of soil, land use and climatic factors on the hydraulic conductivity of soil. Hydrology and Earth System Sciences. 2013;17:5185-5195. 
Krause P, Boyle DP, Bäse F. Comparison of different efficiency criteria for hydrological model assessment. Advances in Geosciences. 2005;5:89-97.

Legates DR, Maccbe GJ. Evaluating the use of "goodnes of fit" measures in hydrologic and hydroclimatic model validation. Water Resources Research. 1999;26:69-86.

Liu L, Chen J. The effect of conservation practices in sloped croplands on soil hydraulic properties and root zone moisture dynamics. Hydrological Processes [Internet] 2015. [cited 2016 nov 12]; 29:2079-2088. Available from: http:// dx.doi.org/10.1002/hyp.10348.

MACADO AR, MELLO JÚNIOR AV, WENDLAND EC. J2000/JAMS model evaluation for Brazilian watersheds hydrological simulation. Engenharia Sanitária e Ambiental. 2017;32(1):327-340. DOI: 10.1590/S1413-41522016145177

Martins MR, Angers DA, Corá JE. Carbohydrate composition and water-stable aggregation of an Oxisol as affected by crop sequence under no-till. Soil Science Society of America Journal. 2012;76:475-484.

Meller A, Collischonn W, Fan FM, Buarque DC, Paiva RCD, Dias PLS, et al. Previsão de cheias por conjunto em curto prazo. Revista Brasileira de Recursos Hídricos. 2014;19(3):33-49.

Moreira IA, Mine MRM, Pereira Filho AJ. Modelagem hidrológica chuva-vazão com dados de radar e pluviômetros. Ingeniería del Agua. 2007;4(2):83-96.

Neto AR, Silva RCV, Collischonn W, Tucci CEM. Simulação na bacia Amazônica com dados limitados: rio Madeira. Revista Brasileira de Recursos Hídricos. 2008;13(3):47-58.

Paiva RCD, Collischonn W, Tucci CEM. Large scale hydrologic and hydrodynamic modeling using limited data and a GIS based approach. Journal of Hydrology. 2011;406:170-181.

Pereira DR, Almeida AQ, Martinez MA, Rosa DRQ. Impacts of deforestation on water balance components of a watershed on the Brazilian East Coast. Revista Brasileira de Ciência do Solo, Viçosa. 2014a;38(4):1350-1358.

Pereira DR, Martinez MA, Almeida AQ, Pruski FF, Silva DD, Zonta JH. Hydrological simulation using SWAT model in headwater basin in southeast Brazil. Engenharia Agrícola, Jaboticabal. 2014b;34(4):789-799.

Pereira DR, Martinez MA, Pruski FF, Silva DD. Hydrological simulation in a basin of typical tropical climate and soil using the SWAT model part I: Calibration and validation tests. Journal of Hydrology: Regional Studies. 2016a;7:14-37.

Pereira DR, Uliana EM, Martinez MA, Silva DD. Desempenho de um modelo hidrológico concentrado e de um semidistribuído na predição de vazões diárias. Irriga. 2016b;21(2):409-424.

Silva PMO, Mello CR, Silva AM, Coelho G. Modelagem da hidrografa de cheia em uma bacia hidrográfica da região Alto Rio Grande. Revista Brasileira de Engenharia Agrícola e Ambiental. 2008;12:258-265.

Souza AP, Mota LL, Zamadei T, Martim CC, Almeida FT, Paulino J. Classificação climática e balanço hídrico climatológico no estado de mato grosso. Revista Nativa. 2013;1:34-43.

TANAKA AA, SOUZA AP, KLAR AE, SILVA AC, GOMES AWA. Evapotranspiração de referência estimada por modelos simplificados para o estado do Mato Grosso. Pesquisa agropecuária brasileira. 2016;51(2):91-104.

Tucci CEM. Modelos hidrológicos. 2. ed. Porto Alegre: UFRGS/ABRH; 2005.

Tucci CEM. Hidrologia: ciência e aplicação. 4.ed. Porto Alegre: UFRGS/ABRH; 2009.

Wendling B, Vinhal-Freitas IC, Oliveira RC, Babata MM, Borges EN. Density, porosity and soil aggregation in areas of cerrado conversion in pine forest, pasture and no-tillage. Bioscience Journal. 2012;28:256-265.

Willmott CJ. Some comments on the evaluation of model performance. Bulletin-American Meteorological Society. 1982;63(11):1309-1313. 